\title{
Sodium valproate blocks the transforming growth factor (TGF)- $\beta 1$ autocrine loop and attenuates the TGF- $\beta 1$-induced collagen synthesis in a human hepatic stellate cell line
}

\author{
TOSHIFUMI WATANABE ${ }^{1,4}$, HIDEHIRO TAJIMA ${ }^{1}$, HAYASHI HIRONORI ${ }^{1}$, HISATOSHI NAKAGAWARA ${ }^{1}$, \\ ICHIRO OHNISHI $^{1}$, HIROYUKI TAKAMURA ${ }^{1}$, ITASU NINOMIYA ${ }^{1}$, HIROHISA KITAGAWA ${ }^{1}$, \\ SACHIO FUSHIDA ${ }^{1}$, TAKASHI TANI ${ }^{1}$, TAKASHI FUJIMURA ${ }^{1}$, TETSUO OTA ${ }^{1}$, \\ TOMOHIKO WAKAYAMA ${ }^{2}$, SHOICHI ISEKI ${ }^{2}$ and SHINICHI HARADA ${ }^{3}$
}

Departments of ${ }^{1}$ Gastroenterological Surgery, ${ }^{2}$ Histology and Embryology and ${ }^{3}$ Center for Biomedical Research and Education, Kanazawa University Graduate School of Medical Science, Kanazawa, Ishikawa 920-8641;

${ }^{4}$ Department of Surgery, Toyama Prefectural Central Hospital, Toyama 930-8550, Japan

Received June 11, 2011; Accepted July 22, 2011

DOI: $10.3892 /$ ijmm.2011.768

\begin{abstract}
Histone acetylation and deacetylation have been thought to be related to gene expression, and there are many reports indicating that histone deacetylase inhibitors (HDACis) exert antifibrogenic effects in several organs. In injured livers, hepatic stellate cells (HSCs) are activated in response to profibrogenic mediators and produce large amounts of extracellular matrix. In particular, transforming growth factor- $\beta 1$ (TGF- $\beta 1$ ) is considered as a key factor in accelerating hepatic fibrosis because it is released from activated HSCs and further stimulates them. The present study aimed to clarify whether sodium valproate (VPA) has suppressive effects on cultured human HSCs (LI90). We showed that treatment with VPA had no significantly suppressive effect on cell proliferation at a concentration of $1 \mathrm{mM}$, which corresponded approximately to the serum concentration obtained by the administration of a clinical dose. However, VPA prevented the morphological changes characteristic for activation and inhibited the expression of collagen type $1 \alpha 1$ (COL1A1) and TGF- $\beta 1$ in activated LI90 cells at the mRNA and protein levels. Our results support the hypothesis that VPA exerts antifibrogenic activity with
\end{abstract}

Correspondence to: Dr Toshifumi Watanabe, Department of Surgery, Toyama Prefectural Central Hospital, Nishinagae 2-2-78, Toyama 930-8550, Japan

E-mail:w10423@hotmail.co.jp

Abbreviations: HDACis, histone deacetylase inhibitors; HSCs, hepatic stellate cells; VPA, valproate; COL1A1, collagen type $1 \alpha 1$; $\alpha$ SMA, $\alpha$ smooth muscle actin

Key words: liver fibrosis, hepatic stellate cell, transforming growth factor- $\beta$, valproate little cytotoxicity at $1 \mathrm{mM}$, and HDACis are expected to be used in clinical practice for the treatment of fibrotic diseases.

\section{Introduction}

Hepatic stellate cells (HSCs) are considered as the main source of extracellular matrix (ECM) proteins in chronic liver diseases leading to fibrosis. In a normal liver, these cells are liver-specific pericytes that serve as major vitamin A storage sites and show little proliferative activity (1). In an injured liver, however, HSCs undergo phenotypic changes termed activation in response to profibrogenic mediators such as platelet-derived growth factor (PDGF), connective tissue growth factor (CTGF), endothelin (ET)-1, and members of the transforming growth factor- $\beta$ (TGF- $\beta$ ) family. During this phenotypic transition, HSCs express $\alpha$ smooth muscle actin $(\alpha \mathrm{SMA})$ and acquire the capacity to proliferate and produce excessive quantities of ECM proteins $(2,3)$. It is reported that TGF- $\beta$ and its intracellular mediators, i.e., Smad proteins, play important roles in stimulating collagen synthesis. In particular, production of TGF- $\beta 1$ is enhanced by activated HSCs, and it has been considered that the effects of TGF- $\beta 1$ on HSCs involve predominantly autocrine stimulation $(4,5)$. Therefore, inhibition of TGF- $\beta 1$ signals seems to be a potential target for therapeutic intervention in patients with liver fibrosis.

It is considered that histone modification, particularly histone acetylation, is a key principle of epigenetic regulation of gene expression (6-8). Histone acetylation and deacetylation is controlled by histone acetyltransferases and histone deacetylases. In recent years, histone deacetylase inhibitors (HDACis) showed anti-cancer activities and are, therefore, of clinical interest (9-12). There are also several reports showing an antifibrogenic effect of HDACis, but the underlying mechanism is still unclear $(2,13-15)$.

In this study, we investigated the antifibrogenic effect of sodium valproate (VPA) on cultured HSCs and its molecular mechanism in vitro. 


\section{Materials and methods}

Chemicals. VPA (molecular weight: 166.2) and recombinant human TGF- $\beta 1$ were purchased from Sigma-Aldrich (St. Louis, $\mathrm{MO})$.

Antibodies. As primary antibodies, we used mouse monoclonal antibodies to $\alpha$ SMA and TGF- $\beta 1$ (Santa Cruz Biotechnology, Inc., Santa Cruz, CA), rabbit polyclonal antibodies to collagen type $1 \alpha 1$ (COL1A1), histone H3, H4, acetylated histone H3 (Ac-H3), acetylated histone H4 (Ac-H4) (Millipore, Billerica, MA), Smad 7, phosphorylated Smad 2 (p-Smad 2), and phosphorylated Smad 3 (p-Smad 3), and a goat polyclonal antibody to Smad 2/3 (Santa Cruz Biotechnology).

Cell culture. Human hepatic stellate cells (LI90; Health Science Research Resources Bank, Osaka, Japan) were seeded at a density of $1.0 \times 10^{4}$ cells $/ \mathrm{ml}$ in collagen type I-coated flasks, 96-well plates (Becton-Dickinson and Company, Franklin Lakes, NJ), or Lab-Tek chamber slides (Nalge Nunc International, New York, NY). The cells were cultured in Dulbecco's modified Eagle's medium (DMEM; Invitrogen, Tokyo, Japan) supplemented with $1 \%(\mathrm{v} / \mathrm{v})$ heat-inactivated fetal bovine serum (FBS; Nichirei Biosciences, Inc., Tokyo, Japan), $100 \mathrm{U} / \mathrm{ml}$ penicillin, and $100 \mu \mathrm{g} / \mathrm{ml}$ streptomycin (Invitrogen) at $37^{\circ} \mathrm{C}$ in a $5 \% \mathrm{CO}_{2}$ humidified atmosphere for $24 \mathrm{~h}$. On the following day, the medium was replaced with DMEM containing 1\% FBS, antibiotics, and VPA and/ or TGF- $\beta 1$ (3 ng/ml TGF- $\beta 1,1 \mathrm{mM}$ VPA, $3 \mathrm{ng} / \mathrm{ml}$ TGF- $\beta 1$ $+1 \mathrm{mM}$ VPA), and the cells were cultured for 7 more days. Normal control cells were cultured in DMEM containing $1 \%$ FBS and antibiotics. The medium was changed every day. At the end of culture, the following analyses were performed.

Cell viability analysis. Cell viability was assessed by using the CellTiter 96 AQueous One Solution Cell Proliferation assay (Promega Corp.oration, Fitchburg, WI) according to the manufacturer's instructions. Briefly, at the end of incubation, $20 \mu \mathrm{l}$ of the reagent 3-(4,5-dimethylthiazol-2-yl)5-(3-carboxymethoxyphenyl)-2-(4-sulfophenyl)-2H-tetrazolium (MTS) was added to $100 \mu \mathrm{l}$ medium in each well. Cells were further cultured for $1 \mathrm{~h}$, and the resultant absorbance was recorded at $490 \mathrm{~nm}$ using a 96-well plate reader (EAR $340 \mathrm{AT}$, SLT, Vienna, Austria). Data represent the mean (SD) of three independent experiments and are expressed as percentage of untreated control cells.

Immunofluorescence. After culturing for 7 days on Lab-Tek chamber slides (Nalge Nunc International), cells were fixed in a mixture of methanol and acetone (1:1) for $15 \mathrm{~min}$. Immunostaining was performed as described (16). Briefly, the slides were blocked with normal goat serum $[5 \%$ in phosphatebuffered saline (PBS)] and incubated with a mouse monoclonal antibody against $\alpha$ SMA (1:100) (Santa Cruz Biotechnology) or a rabbit polyclonal antibody to COL1A1 (1:100) (Santa Cruz Biotechnology) at $4^{\circ} \mathrm{C}$ overnight. Next, the slides were washed in PBS and the immunoreactivity was visualized by incubating the slides with a goat anti-mouse $\operatorname{IgG}$ antibody conjugated with Alexa Fluor 488 (Invitrogen) (1:400) for $1 \mathrm{~h}$ at room temperature. The slides were counterstained with bis-benzimide (Hoechst 33258, $100 \mathrm{ng} / \mathrm{ml}$; Sigma-Aldrich) to visualize the nuclei. The slides were then examined under a fluorescence microscope (Olympus BX51; Olympus, Tokyo, Japan).

Immunoblotting. The cells were harvested by trypsinization with $0.25 \%$ trypsin-EDTA (Invitrogen), washed 3 times with PBS, and dissolved in RIPA buffer (Wako Pure Chemical Industries, Ltd., Osaka, Japan) containing a protease and phosphatase inhibitor cocktail (Sigma-Aldrich). The protein concentration of each sample was measured using a BCA protein assay kit (Thermo Scientific, Waltham, MA). For sodium dodecyl sulfate-polyacrylamide gel electrophoresis (SDS-PAGE), $20 \mu \mathrm{g}$ protein of each sample were loaded on a 5-20\% gradient polyacrylamide gel (e-PAGEL, ATTO Corp., Tokyo, Japan). Proteins were transferred to polyvinylidene difluoride (PVDF) membranes (ATTO Corp.) and then blocked with gradient buffer (EzBlock, ATTO Corp.) at room temperature for $30 \mathrm{~min}$. The membranes were incubated with a mouse anti-TGF- $\beta 1$ antibody $(1: 1,000)$, a rabbit anti-COL1A1 antibody $(1: 1,000)$, anti-p-Smad 2 antibody $(1: 1,000)$, anti-p-Smad 3 antibody (1:1,000), anti-Smad 7 antibody (1:1,000), anti-histone H3 antibody (1:5,000), anti-Ac-H3 antibody (1:5,000), anti-histone H4 antibody $(1: 5,000)$, anti-Ac-histone H4 antibody $(1: 5,000)$ and a goat anti-Smad $2 / 3$ antibody $(1: 1,000)$ overnight at $4^{\circ} \mathrm{C}$. After washing with gradient buffer (EzWash, ATTO Corp.), the membranes were incubated with a horseradish peroxidaselabeled anti-mouse or anti-rabbit IgG antibody (GE Healthcare UK, Ltd., Buckinghamshire, UK) or anti-goat IgG antibody (Santa Cruz Biotechnology) for $1 \mathrm{~h}$ at room temperature. The antibody-antigen complex was detected by using the ECL Plus Western blotting detection system (GE Healthcare) and quantified as described previously (17). We used $\beta$-actin as an internal control.

Quantitative real-time reverse transcription-polymerase chain reaction (real-time RT-PCR). Total-RNA was extracted from LI90 cells using the RNeasy mini kit (Qiagen, Venlo, Netherlands) according to the manufacturer's instructions. Next, 100 ng total-RNA were reverse transcribed to cDNA using the High-Capacity cDNA Reverse Transcription kit (Applied Biosystems, Foster City, CA). TaqMan quantitative real-time PCR was performed in triplicate on a Mx3005P Real-Time QPCR System (Agilent Technologies Japan, Ltd., Tokyo, Japan) using predesigned primer sets for COL1A1 (assay ID Hs01076775_g1), TGF- $\beta 1$ (assay ID Hs00998129_ m1) (TaqMan assays-on-demand, Applied Biosystems, Nieuwerkerk a/d IJssel, The Netherlands), and the housekeeping gene glyceraldehyde-3-phosphate dehydrogenase [GAPDH; TaqMan GAPDH Control Reagents (Human)]. The cycling conditions consisted of polymerase activation at $95^{\circ} \mathrm{C}$ for $10 \mathrm{~min}$, followed by 40 cycles at $95^{\circ} \mathrm{C}$ for $15 \mathrm{sec}$ and $60^{\circ} \mathrm{C}$ for $60 \mathrm{sec}$. Threshold cycle $(\mathrm{Ct})$ values of the target genes were normalized to that of GAPDH. Relative expression in each sample compared to the control sample was calculated according to the $2^{-\Delta \Delta \mathrm{Ct}}$ method (18).

Statistical analysis. Statistical analyses were carried out using Welch's t-test. Probability values $<0.05$ were considered statistically significant. 
A

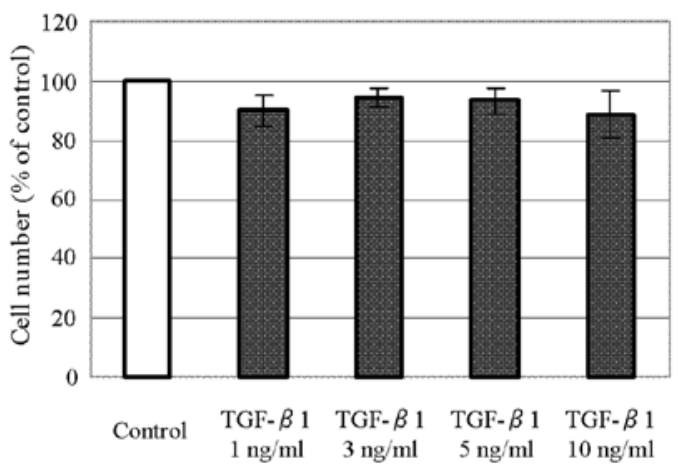

B

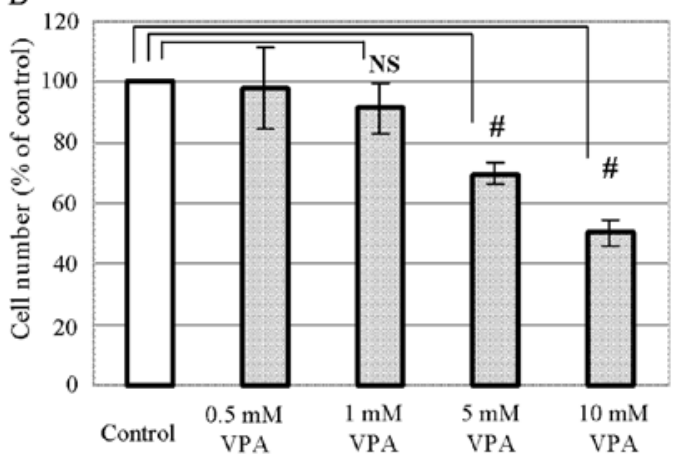

C

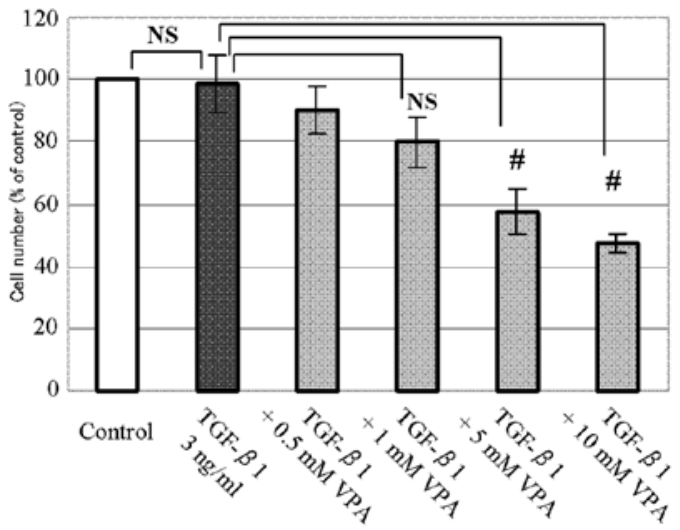

Figure 1. Treatment of LI90 cells with various concentrations of TGF- $\beta 1$ or VPA. (A) A slight suppressive effect of TGF- $\beta 1$ on cell proliferation. (B and C) Dose-dependent reduction of cell viability by VPA. VPA significantly inhibited cell proliferation at concentrations $\geq 5 \mathrm{mM}$. Data represent the mean (SD) of three independent experiments. Statistically significant differences were determined by the Welch's t-test. ${ }^{\#} \mathrm{P}<0.01$; NS, not significant; TGF- $\beta 1$, transforming growth factor- $\beta 1$; VPA, sodium valproate.

\section{Results}

A high dose of VPA inhibits the proliferation of LI90 cells. First, we examined the effects of TGF- $\beta 1$ or VPA on cell proliferation using the MTS assay as described above. Treatment with TGF- $\beta 1$ did not show significant stimulatory or inhibitory effects on the proliferation of LI90 cells (Fig. 1A). Treatment with VPA reduced the cell number in a concentration-dependent manner (Fig. 1B). Statistically significant inhibition of cell proliferation after VPA exposure was observed at concentrations of $5 \mathrm{mM}[69.8(3.6) \%, \mathrm{P}=0.0047]$ and $10 \mathrm{mM}$ [50.3 (4.2)\%, $\mathrm{P}=0.0024]$, but the inhibition did not reach statistical significance at a concentration of $1 \mathrm{mM}[91.2$
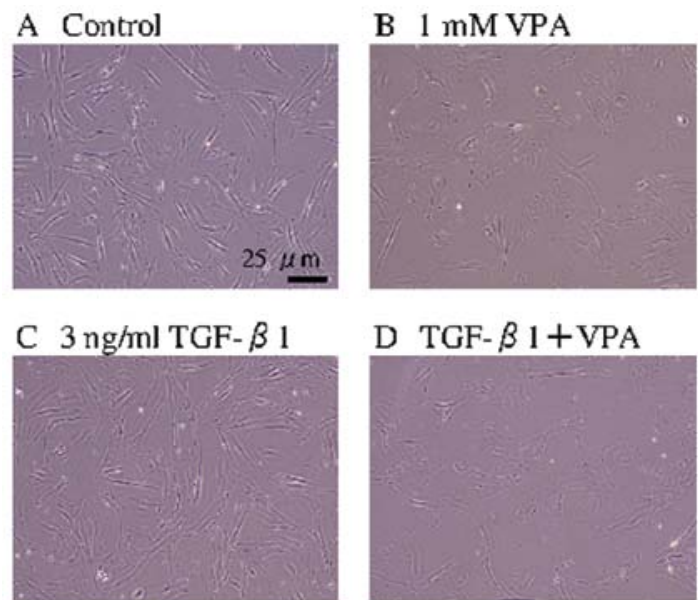

D TGF- $\beta 1+$ VPA

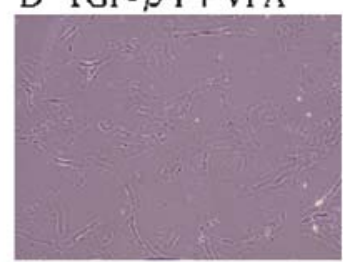

Figure 2. Phase contrast microscopic findings. (A and C) Untreated control group showed myofibroblast-like morphology after incubation for 7 days and TGF- $\beta 1$ ( $3 \mathrm{ng} / \mathrm{ml})$ accelerated the morphological change. VPA $(1 \mathrm{mM})$ treatment inhibited the activation (B and D). TGF- $\beta 1$, transforming growth factor- $\beta 1$; VPA, sodium valproate.
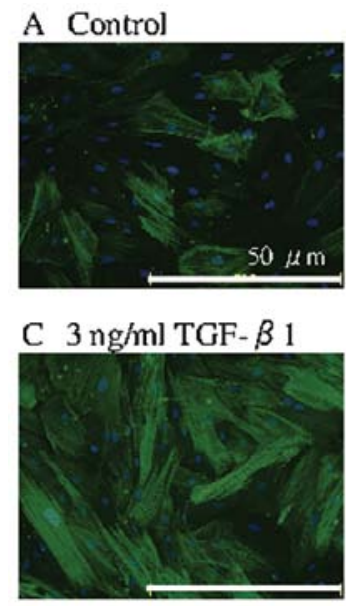

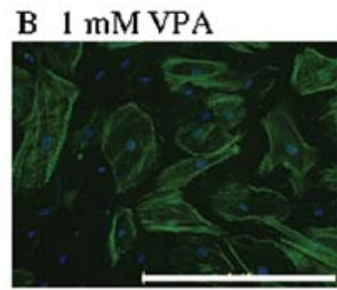

D TGF- $\beta 1+\mathrm{VPA}$

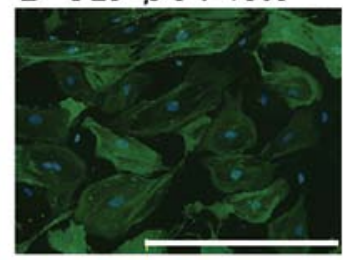

Figure 3. Fluorescence immunocytochemistry for $\alpha$ SMA. (A) Activation of LI90 cells is accompanied by induction of $\alpha$ SMA. (C) TGF- $\beta 1(3 \mathrm{ng} / \mathrm{ml})$ accelerated the activation. (B and D) HSCs treated with $1 \mathrm{mM}$ VPA showed a decrease in $\alpha$ SMA fibers. $\alpha$ SMA, $\alpha$ smooth muscle actin; TGF- $\beta 1$, transforming growth factor- $\beta 1$; HSCs, hepatic stellate cells; VPA, sodium valproate.

(8.5)\%, $\mathrm{P}=0.21]$. We also investigated the viability of the cells treated with TGF- $\beta 1(3 \mathrm{ng} / \mathrm{ml})$ and various concentrations of VPA $(0.5,1.0,5.0$ and $10 \mathrm{mM})$. Similar to treatment with VPA alone, significant inhibition was observed at concentrations $\geq 5 \mathrm{mM}$ (Fig. 1C).

VPA inhibits HSC activation at a concentration of $1 \mathrm{mM}$. To investigate whether VPA inhibits the activation of HSCs, we treated LI90 cells as indicated and performed immunofluorescence studies. After incubation for 7 days, untreated LI90 cells showed myofibroblast-like morphology (Fig. 2A), and the morphological changes were accompanied by induction of $\alpha$ SMA expression (Fig. 3A). TGF- $\beta 1$ accelerated these morphological alterations (Fig. 2C) and the expression of aSMA (Fig. 3C), while VPA inhibited the activation (Figs. 2B and $3 \mathrm{~B}$ ) and attenuated the TGF- $\beta 1$-induced activation (Figs. 2D and 3D). 

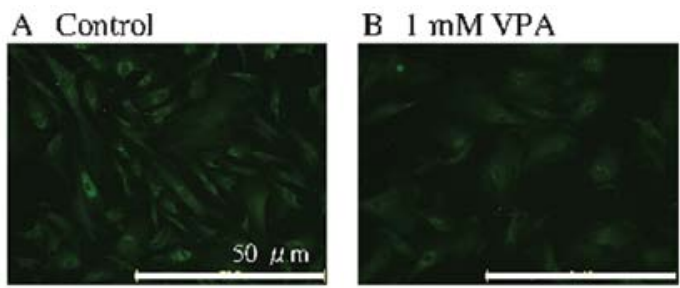

C $3 \mathrm{ng} / \mathrm{ml}$ TGF- $\beta 1$
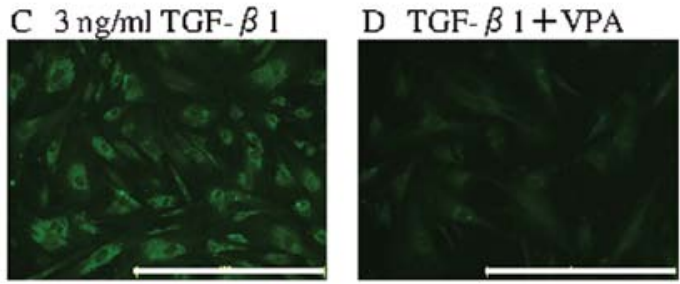

Figure 4. Immunofluorescence for COL1A1 in LI90 cells. (A) COL1A1 protein synthesis in activated LI90 cells. (C) Acceleration of the synthesis of COL1A1 byTGF- $\beta 1$. (B) VPA did not significantly influence the basal COL1A1 synthesis, but (D) it markedly attenuated the TGF- $\beta 1$-induced upregulation of COL1A1 synthesis (D). COL1A1, collagen type $1 \alpha 1$; TGF- $\beta 1$, transforming growth factor- $\beta 1$; VPA, sodium valproate.

VPA attenuates TGF- $\beta 1$-stimulated levels of COL1A1 protein and $m R N A$. Next, we evaluated the levels of COL1A1 expression in each group. TGF- $\beta 1$-treated cells showed increased COL1A1 protein synthesis compared to control cells (Fig. 4A and C). Densitometry analysis of Western blot analyses of 3 separate experiments showed that the COL1A1 protein levels of the TGF- $\beta 1$-treated group were significantly increased by $24.5 \%$ compared to that of the untreated group $(\mathrm{P}=0.042)$ (Fig. 5A and B). In our experiments, VPA scarcely influenced the basal COL1A1 protein expression (Figs. 4B and 5A and B), but it decreased the TGF- $\beta 1$-stimulated COL1A1 protein expression by $17.8 \%(\mathrm{P}=0.013$ ) (Figs. $4 \mathrm{D}$ and $5 \mathrm{~A}$ and $\mathrm{B}$ ).

Similar to the changes at the protein level, TGF- $\beta 1$ treatment resulted in a statistically significant increase in COL1A1 mRNA expression by $111 \%$ compared to that of the untreated cells $(\mathrm{P}=0.023)$ (Fig. 5C). The COL1A1 mRNA expression level of cells treated with VPA alone was almost the same as that of untreated cells, but VPA treatment suppressed the TGF- $\beta 1$-induced up-regulation of COL1A1 mRNA (21.2\%, $\mathrm{P}=0.0040$ ) (Fig. 5C).

VPA treatment affects the expression of TGF- $\beta 1$ at the protein and mRNA levels. We also examined whether VPA affects the expression of TGF- $\beta 1$, which is an activator of HSCs. The expression of TGF- $\beta 1$ following treatment with $3 \mathrm{ng} / \mathrm{ml} \mathrm{TGF}-\beta 1$ was increased by $76.3 \%$ compared to that of the controls $(\mathrm{P}=0.0023)$ (Fig. 6A and B). However, TGF- $\beta 1$ expression of cells treated with $3 \mathrm{ng} / \mathrm{ml}$ TGF- $\beta 1$ and $1 \mathrm{mM}$ VPA was almost the same as that of the control cells. This finding indicated that VPA treatment attenuated the TGF- $\beta 1$-induced up-regulation of TGF- $\beta 1$ protein expression by $41.4 \%(\mathrm{P}=0.0105)$. Following treatment with $3 \mathrm{ng} / \mathrm{ml}$ TGF- $\beta 1$, the expression of TGF- $\beta 1$ mRNA was increased by $133 \%$ compared to that of the control cells $(\mathrm{P}=0.0008)$, and treatment with VPA and TGF- $\beta 1$ resulted in a decrease in TGF- $\beta 1 \mathrm{mRNA}$ expression of $59.6 \%(\mathrm{P}=0.0015)$ (Fig. 6C). Similar to the expression of COL1A1, the protein and mRNA expression of TGF- $\beta 1$ were not significantly altered by VPA treatment alone.
A

\section{COL1A1}

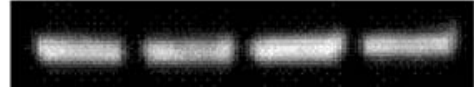

$\beta$-actin

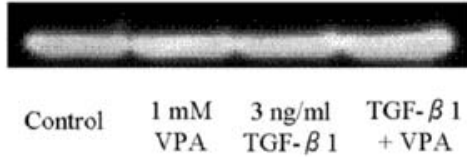

B
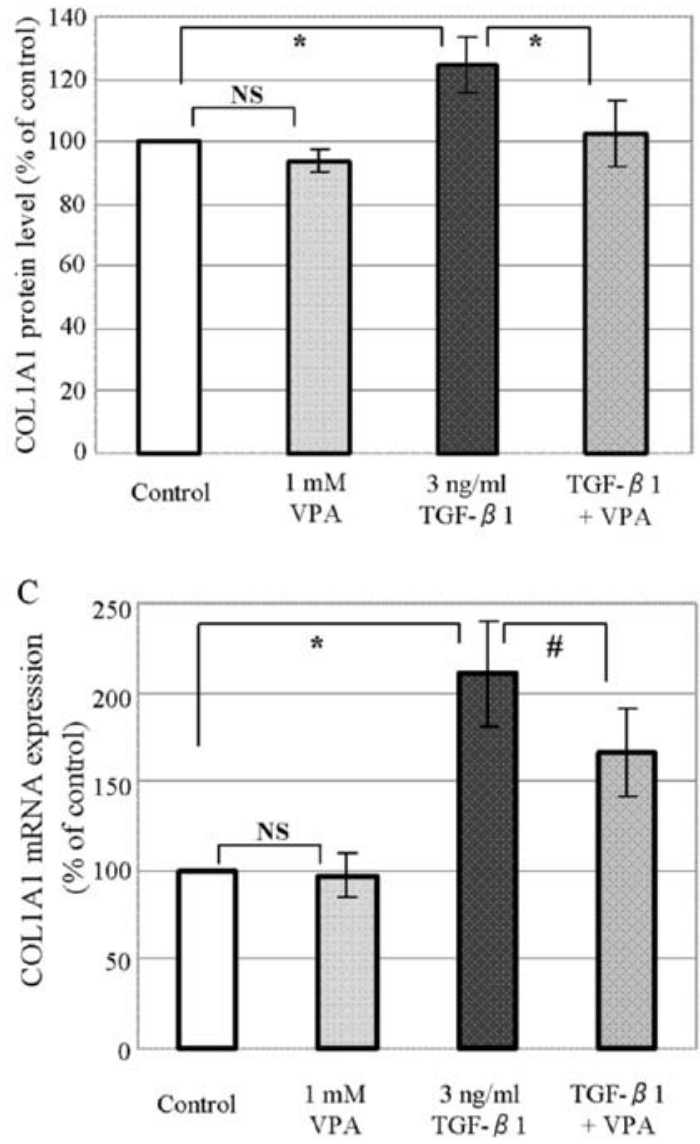

Figure 5. (A and B) Western blot analysis of COL1A1. VPA attenuated the TGF- $\beta 1$-induced increase in COL1A1 protein expression by $17.8 \%$ $(\mathrm{P}=0.013)$. (C) Real-time RT-PCR for COL1A1 mRNA expression. TGF- $\beta 1$ markedly increased the COL1A1 mRNA expression compared to the control levels $(\mathrm{P}=0.023)$, and VPA suppressed the TGF- $\beta 1$-stimulated up-regulation of COL1A1 mRNA expression ( $\mathrm{P}=0.004)$. Data represent the mean (SD) of three independent experiments. Statistically significant differences were determined by the Welch's t-test. ${ }^{*} \mathrm{P}<0.05$; ${ }^{*} \mathrm{P}<0.01$; NS, not significant; COL1A1, collagen type $1 \propto 1$; VPA, sodium valproate; RT-PCR, reverse transcriptase-polymerase chain reaction; TGF- $\beta 1$, transforming growth factor- $\beta 1$.

Expression and phosphorylation of Smad 2/3 are suppressed by VPA. Furthermore, we investigated the expression of Smad proteins, which are components of TGF- $\beta$ signaling. The expression and phosphorylation of Smad 2/3 were up-regulated in the presence of TGF- $\beta 1$, and the TGF- $\beta 1$-induced up-regulation was attenuated in the presence of VPA. In fact, changes in the expression of Smad 2/3 were similar to that observed for TGF- $\beta 1$ (Fig. 7). VPA alone had no effect on the expression and phosphorylation of Smad 2/3. The expression of Smad 7 was not different in each group. 
A

TGF- $\beta 1$

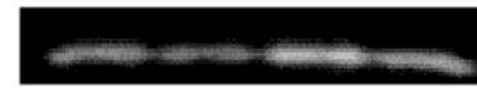

$\beta$-actin

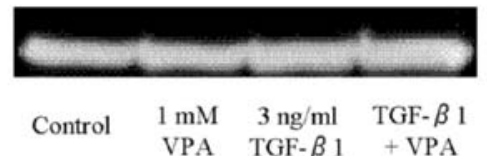

B

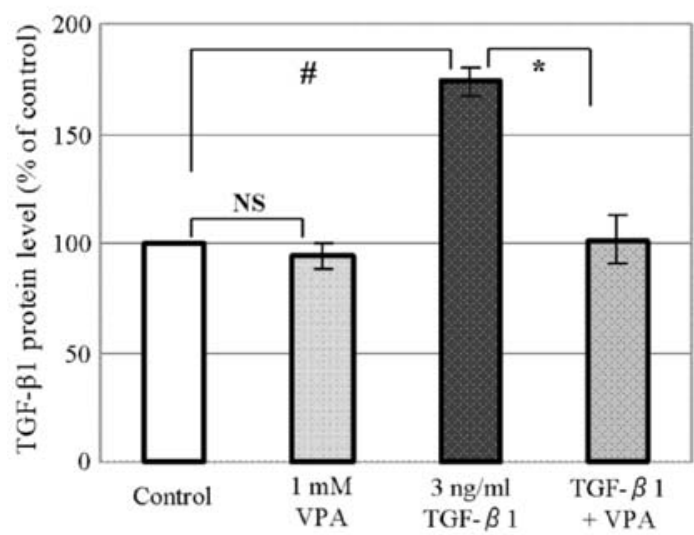

$\mathrm{C}$

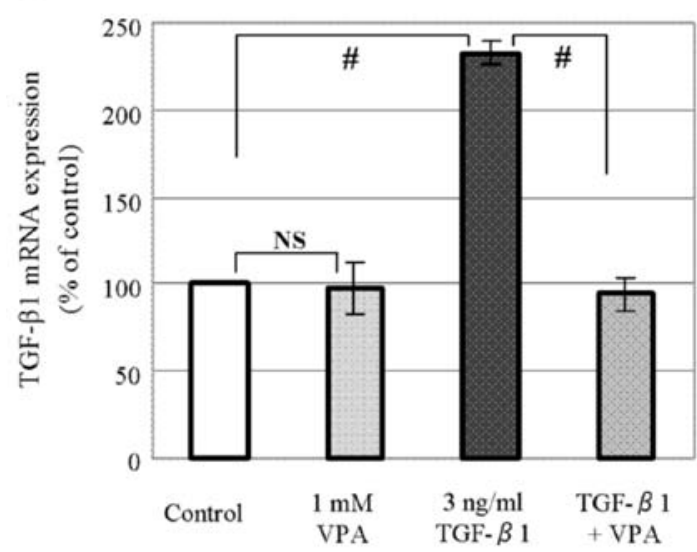

Figure 6. (A and B) Western blot analysis of TGF- $\beta 1$. Treatment with TGF- $\beta 1$ increased the TGF- $\beta 1$ protein expression by $73.6 \%$ compared to the untreated controls $(\mathrm{P}=0.0023)$. VPA attenuated the TGF- $\beta 1$-induced up-regulation of the TGF- $\beta 1$ protein expression by $41.4 \%(\mathrm{P}=0.0105)$. (C) Real-time RT-PCR for TGF- $\beta 1$ mRNA expression. TGF- $\beta 1$ markedly increased the TGF- $\beta 1$ mRNA expression compared to the control level $(\mathrm{P}=0.0008)$, and VPA suppressed the TGF- $\beta 1$-induced up-regulation of the TGF- $\beta 1$ mRNA expression $(\mathrm{P}=0.0015)$. Data represent the mean $(\mathrm{SD})$ of 3 different experiments. Statistically significant differences were determined by the Welch's t-test. ${ }^{*} \mathrm{P}<0.05$; ${ }^{\text {}} \mathrm{P}<0.01$; NS, not significant; TGF- $\beta 1$, transforming growth factor- $\beta 1$; RT-PCR, reverse transcriptase-polymerase chain reaction; VPA, sodium valproate.

Hyperacetylation of histone $\mathrm{H} 3$ and $\mathrm{H} 4$ are maintained after 7 days of treatment with VPA. In LI90 cells treated with VPA, we found increased levels of the acetylated histones $\mathrm{H} 3$ and H4 compared to cells not treated with VPA (Fig. 8).

\section{Discussion}

Histone modifications, such as acetylation, phosphorylation, methylation, and ubiquitination, have been shown to be a key
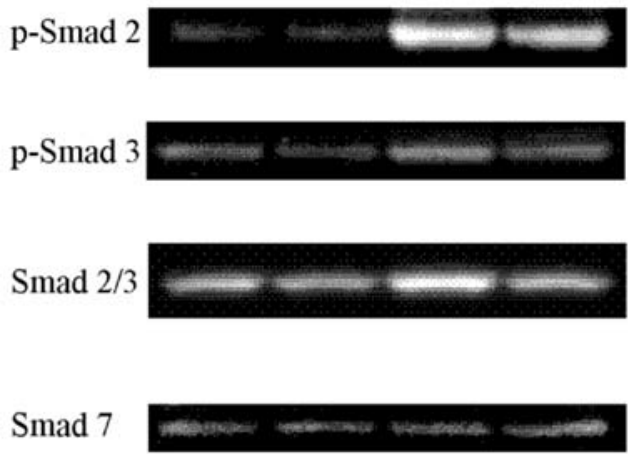

$\beta$-actin

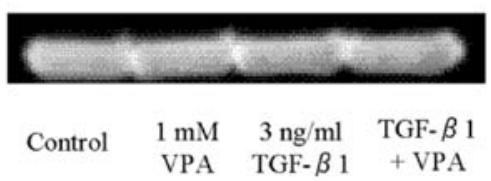

Figure 7. Western blot analysis of Smad 2/3 and 7. The changes in the expression and phosphorylation of Smad 2/3 were similar to those observed for TGF- $\beta 1$. Smad 7 was not influenced by TGF- $\beta 1$ or VPA treatment. TGF- $\beta 1$, transforming growth factor- $\beta 1$; VPA, sodium valproate.

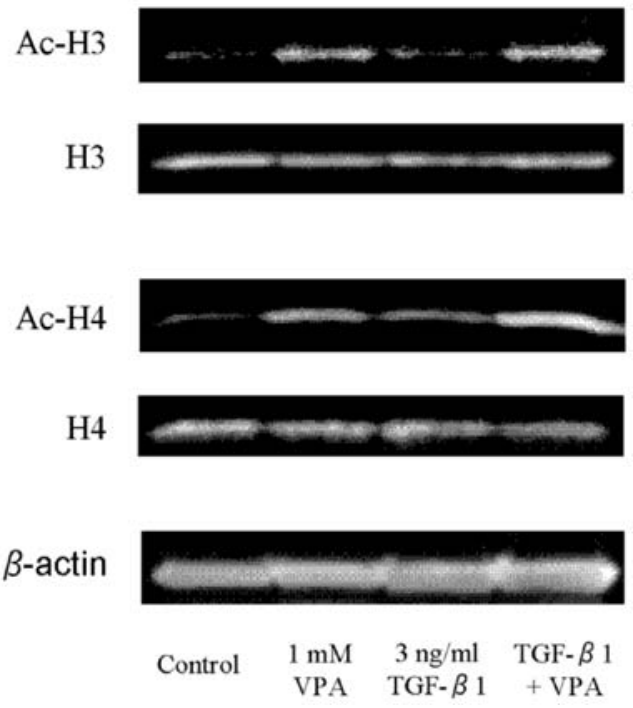

Figure 8. Western blot analysis of $\mathrm{H} 3, \mathrm{H} 4$, acetylated (Ac)-H3 and Ac-H4. VPA caused hyperacetylation of histone $\mathrm{H} 3$ and $\mathrm{H} 4$. VPA, sodium valproate.

regulatory mechanism of transcriptional regulation $(6,19)$. Recent studies have shown that HDACis have the potential to inhibit carcinogenesis and fibrogenesis (2,9-15). VPA, a semiselective HDACi (20), is widely prescribed for patients with epilepsy and psychiatric disorders and well tolerated by the majority of patients $(21,22)$. We examined whether VPA had antifibrogenic effects on human HSCs at a concentration of $1 \mathrm{mM}$, which corresponded approximately to the serum levels obtained by administration of a clinical dose.

We first confirmed the effects of TGF- $\beta 1$ and VPA on the proliferation of LI90 cells to determine the appropriate concentrations of these compounds used in the exposure experiments. In our experiments, TGF- $\beta 1$ exerted no significant effect on the proliferation, with only a tendency for slight suppression. This result is in agreement with a previous report (23). In addition, Shirai et al (24) have shown that the plasma TGF- $\beta 1$ levels in 
patients with chronic hepatitis was $3.0(3.1) \mathrm{ng} / \mathrm{ml}$ [mean (SD)], and we thus considered it appropriate to expose LI90 cells to $3 \mathrm{ng} / \mathrm{ml}$ TGF- $\beta 1$ in order to mimic an injured liver. While VPA significantly inhibited the cell proliferation at concentrations $\geq 5 \mathrm{mM}$ or more, the decrease did not reach statistical significance at a concentration of $1 \mathrm{mM}$. This result indicated that VPA at a concentration of $1 \mathrm{mM}$ had little cytotoxicity. In addition, according to a clinical trial of VPA in patients with refractory advanced cancer (25), the maximum serum concentration following intravenous administration of VPA $(<60 \mathrm{mg} / \mathrm{kg}$ ) did not exceed $200 \mathrm{mg} / \mathrm{l}$ and no dose-limiting toxicity was observed. On the basis of these facts, we decided to treat LI90 cells with $1 \mathrm{mM}$ VPA. Treatment with $3 \mathrm{ng} / \mathrm{ml}$ TGF- $\beta 1$ and $1 \mathrm{mM}$ VPA also did not result in a significant decrease in the cell number compared to that of cells treated with TGF- $\beta 1$ alone.

After treatment with $1 \mathrm{mM}$ VPA alone for 7 days, a tendency for inhibition of morphological changes was observed, but we could not confirm a significant suppression of COL1A1 synthesis and TGF- $\beta 1$ expression. It was reported that the synthesis of collagens and TGF- $\beta 1$ were not effectively inhibited when transition into myofibroblasts had already occurred (1). We received LI90 cells from passages 16-18, and most of them showed myofibroblast-like morphology after $24 \mathrm{~h}$ of incubation (data not shown). Therefore, we concluded that cells had been already activated when treatment with VPA began. This may also be the reason why VPA alone had no inhibitory effect on HSCs in our experiments.

Freshly isolated HSCs undergo transition from a quiescent to an activated phenotype after culture for a few days to about a week $(1,26)$. The present study confirmed that exogenous TGF- $\beta 1$ accelerated the phenotypic change and caused enhanced up-regulation of COL1A1 and TGF- $\beta 1$ expression. As mentioned above, treatment with VPA alone had no significant effects on the basal COL1A1 and TGF- $\beta 1$ expression, but VPA at a concentration of $1 \mathrm{mM}$ markedly attenuated the TGF- $\beta 1$-induced up-regulation of COL1A1 synthesis. In addition, VPA reversed the TGF- $\beta 1$-induced increase in the expression of TGF- $\beta 1$ at the protein and mRNA levels to the control level. The present findings, therefore, suggest that the inhibitory effects of VPA on the collagen synthesis accelerated by exogenous TGF- $\beta 1$ are, at least in part, due to suppression of TGF- $\beta 1$ at the transcriptional level. Our data indicate that the changes in the Smad 2/3 expression are similar to those observed for TGF- $\beta 1$. In addition, the expression of Smad 7 was not altered in the presence of VPA. On the basis of these results, we conclude that VPA did not affect the expression of Smad proteins. It remains controversial whether HDACis act directly or indirectly on the expression and phosphorylation of Smad proteins $(27,28)$.

After 7 days of incubation, acetylation of histone $\mathrm{H} 3$ and $\mathrm{H} 4$ of cells treated with VPA was maintained. Therefore, histone remodeling seemed to be associated with the antifibrogenic effects shown in our study. Further studies are required to determine factors that affect the expression of TGF- $\beta 1$ and to analyze the relationship between these factors and histone remodeling.

In conclusion, our study showed that the mechanism by which VPA acts on TGF- $\beta 1$-induced hepatic fibrosis could be in part via the suppression of the transcription of TGF- $\beta 1$ and that VPA is expected to be applied in clinical practice for the treatment of fibrotic diseases.

\section{References}

1. Niki T, Rombouts K, De Bleser P, et al: A histone deacetylase inhibitor, trichostatin A, suppresses myofibroblastic differentiation of rat hepatic stellate cells in primary culture. Hepatology 29: 858-867, 1999.

2. Bülow R, Fitzner B, Sparmann G, Emmrich J, Liebe S and Jaster R: Antifibrogenic effects of histone deacetylase inhibitors on pancreatic stellate cells. Biochem Pharmacol 74: 1747-1757, 2007.

3. Brenner DA: Molecular pathogenesis of liver fibrosis. Trans Am Clin Climatol Assoc 120: 361-368, 2009.

4. George J, Wang SS, Sevcsik AM, Sanicola M, Cate RL, Koteliansky VE and Bissell DM: Transforming growth factor- $\beta$ initiates wound repair in rat liver through induction of the EIIIAfibronectin splice isoform. Am J Pathol 156: 115-124, 2000.

5. Arias M,Lahme B, Van de Leur E, Gressner AM and Weiskirchen R: Adenoviral delivery of an antisense RNA complementary to the $3^{\prime}$ coding sequence of transforming growth factor- $\beta 1$ inhibits fibrogenic activities of hepatic stellate cells. Cell Growth Differ 13: 265-273, 2002.

6. Khan AU and Krishnamurthy S: Histone modifications as key regulators of transcription. Front Biosci 10: 866-872, 2005.

7. Fuks F: DNA methylation and histone modifications: teaming up to silence genes. Curr Opin Genet Dev 15: 490-495, 2005.

8. Gavin DP, Kartan S, Chase K, Jayaraman S and Sharma RP: Histone deacetylase inhibitors and candidate gene expression: An in vivo and in vitro approach to studying chromatin remodeling in a clinical population. J Psychiatr Res 43: 870-876, 2009.

9. Yamaguchi J, Sasaki M, Sato Y, et al: Histone deacetylase inhibitor (SAHA) and repression of EZH2 synergistically inhibit proliferation of gallbladder carcinoma. Cancer Sci 101: 355-362, 2010.

10. Tatebe H, Shimizu M, Shirakami Y, Sakai H, Yasuda Y, Tsurumi H and Moriwaki H: Acyclic retinoid synergises with valproic acid to inhibit growth in human hepatocellular carcinoma cells. Cancer Lett 285: 210-217, 2009.

11. Catalano MG, Poli R, Pugliese M, Fortunati N and Boccuzzi G: Valproic acid enhances tubulin acetylation and apoptotic activity of paclitaxel on anaplastic thyroid cancer cell lines. Endocr Relat Cancer 14: 839-845, 2007.

12. Haefner M, Bluethner T, Niederhagen M, et al: Experimental treatment of pancreatic cancer with two novel histone deacetylase inhibitors. World J Gastroenterol 14: 3681-3692, 2008.

13. Rombouts K, Niki T, Greenwel P, et al: Trichostatin A, a histone deacetylase inhibitor, suppresses collagen synthesis and prevents TGF- $\beta 1$-Induced fibrogenesis in skin fibroblasts. Exp Cell Res 278: 184-197, 2002.

14. Lee TM, Lin MS and Chang NC: Inhibition of histone deacetylase on ventricular remodeling in infarcted rats. Am J Physiol Heart Circ Physiol 293: H968-H977, 2007.

15. RishikofDC, RicuperoDA,Liu Hand Goldstein RH: Phenylbutyrate decreases type I collagen production in human lung fibroblasts. J Cell Biochem 91: 740-748, 2004.

16. Nakanuma S, Tajima H, Ohta T, et al: Tumor-derived trypsin enhances proliferation of intrahepatic cholangiocarcinoma cells by activating protease-activated receptor-2. Int J Oncol 36: 793-800, 2010.

17. Yagi Y, Fushida S, Ohta T, et al: Effects of valproic acid on the cell cycle and apoptosis through acetylation of histone and tubulin in a scirrhous gastric cancer cell line. J Exp Clin Cancer Res 29: 149-159, 2010.

18. Livak KJ and Schmittgen TD: Analysis of relative gene expression data using real-time quantitative PCR and the $2^{-\Delta \Delta \mathrm{CT}}$ method. Methods 25: 402-408, 2001.

19. Xu W, Chen H, Du K, et al: A transcriptional switch mediated by cofactor methylation. Science 294: 2507-2511, 2001.

20. Gurvich N, Tsygankova OM, Meinkoth JL and Klein PS: Histone deacetylase is a target of valproic acid-mediated cellular differentiation. Cancer Res 64: 1079-1086, 2004.

21. So CC and Wong KF: Valproate-associated dysmyelopoiesis in elderly patients. Am J Clin Pathol 118: 225-228, 2002.

22. Solanki RK, Singh P, Khandelwal R and Midha A: Efficacy and tolerability of injectable sodium valproate in patients with mania. Indian J Psychiatry 48: 118-120, 2006. 
23. Chang YZ, Yang L and Yang CQ: Migration of hepatic stellate cells in fibrotic microenvironment of diseased liver model. Hepatobiliary Pancreat Dis Int 7: 401-405, 2008.

24. Shirai Y, Kawata S, Tamura S, et al: Elevated levels of plasma transforming growth factor-beta in patients with hepatocellular carcinoma.Comparison with chronic liver diseases. Cancer 73 : 2275-2279, 1994.

25. Atmaca A, Al-Batran SE, Maurer A, et al: Valproic acid (VPA) in patients with refractory advanced cancer: a dose escalating phase I clinical trial. Br J Cancer 97: 177-182, 2007.

26. Mousavi SA, Fønhus MS and Berg T: Up-regulation of uPARAP/ Endo180 during culture activation of rat hepatic stellate cells and its presence in hepatic stellate cell lines from different species. BMC Cell Biol 10: 39-49, 2009.
27. Yoshikawa M, Hishikawa K, Marumo T and Fujita T: Inhibition of histone deacetylase activity suppresses epithelial-to-mesenchymal transition induced by TGF- $\beta 1$ in human renal epithelial cells. J Am Soc Nephrol 18: 58-65, 2007.

28. Ghosh AK, Mori Y, Dowling E and Varga J: Trichostatin A blocks TGF- $\beta$-induced collagen gene expression in skin fibroblasts: involvement of Sp1. Biochem Biophys Res Commun 354: 420-426, 2007. 